\title{
Aplikasi Bokashi Cair Berbahan Dasar Berbeda terhadap Pertumbuhan Sentro (Centrocema pubescens)
}

Maria Julia Dacosta Seran ${ }^{\mathrm{a}}$

${ }^{a}$ Fakultas Pertanian, Universitas Timor, Kefamenanu, TTU - NTT, 85613, Indonesia, email: seranjulia96@gmail.com

${ }^{a}$ Faculty of Agriculture, Timor University, Kefamenanu, TTU - NTT, 85613, Indonesia, email: seranjulia96@ gmail.con

\section{Article Info}

\section{Article history:}

Received 29 Maret 2021

Received in revised form 05 April 202

Accepted 12 April 202

DOI:

https://doi.org/10.32938/ja.v6i2.1353

\section{Keywords:}

Bokashi Cair

Sentro (Centrocema Pubescens)

Pertumbuhan

\section{Abstrak}

Penelitian ini telah dilaksanakan selama 75 hari, terhitung dari awal September sampai awal November 2020 di kebun percobaan Fakultas Pertanian Universitas Timor. Tujuan penelitian ini adalah untuk mengetahui aplikasi bokashi cair berbahan dasar berbeda terhadap pertumbuhan sentro (Centrocema pubescens). Metode penelitian yang digunakan dalam penelitian ini adalah Rancangan Acak Lengkap (RAL) yang terdiri dari 4 perlakuan dan 4 ulangan sehingga terdapat 16 unit percobaan. Perlakuan yang diberikan antara lain R0 = Tanpa bokashi cair, R1 = Bokashi cair berbahan dasar feses sapi, R2 = Bokashi cair berbahan dasar feses Kambing, R3 = Bokashi cair berbahan dasar ekskreta ayam. Variabel yang diuji meliputi jumlah daun, diameter batang, dan panjang penyebaran. Hasil analisis sidik ragam menunjukkan bahwa perlakuan yang diberi bokashi cair dari bahan dasar ekskreta ayam berpengaruh nyata $(\mathrm{P}<0,05)$ dimana perlakuan bokashi cair dari bahan dasar ekskreta ayam (R3) lebih baik dibandingkan dengan yang diberi bokashi cair dari jenis lainnya, yaitu dengan jumlah daun sebanyak 28,72 helai, diameter batang $0,29 \mathrm{~cm}$, dan panjang penyebaran 14,08 . Dapat disimpulkan bahwa bokashi cair berbahan dasar ekskreta ayam menghasilkan pertumbuhan yang baik pada tanaman Sentro (Centrocema pubencens), yaitu dengan jumlah daun sebanyak 18,72 helai, diameter batang $0,29 \mathrm{~cm}$, dan panjang penyebaran $14,08 \mathrm{~cm}$.

\section{Pendahuluan}

Penyediaan bahan makanan bagi ternak ruminansia merupakan bagian penting dalam manajemen pakan, yang mendukung tercapainya produktivitas ternak, yang sejalan dengan program pemerintah dalam rangka mencapai swasembada daging. Bahan pakan bagi ternak ruminansia dapat berasal dari hijauan baik dari jenis rumput maupun legum. Salah satu jenis legum yang tergolong baik dan banyak dimanfaatkan sebagai pakan ternak adalah legum sentro (Centrocema pubescens)

Centrosema pubescens adalah tanaman yang berasal dari Amerika Selatan dan telah ditanam di daerah tropik dan sub tropik dan sering disebut sentro. Namun budidaya tanaman ini masih jarang kita temukan di masyarakat karena kurangnya pengetahuan masyarakat tentang manfaat dari tanaman Centrosema pubescens. Untuk meningkatkan produktivitas dari legum sentro maka faktor kesuburan tanah perlu diperhatikan. Kesuburan tanah sangat penting bagi produksi hijauan makanan ternak, sebab pertumbuhan, produksi dan mutu hijauan hanya dapat dicapai apabila semua faktor yang mendukung pertumbuhan dapat dipenuhi dengan baik, salah satunya melalui teknik pemupukan yang bertujuan meningkatkan nilai kesuburan tanah dengan memanfaatkan limbah kotoran ternak.

Kotoran sapi adalah limbah dari usaha peternakan sapi yang bersifat padat dan dalam proses pembuangannya sering bercampur dengan urin dan gas, seperti metana dan ammonia. Kandungan unsur hara dalam kotoran sapi bervariasi tergantung pada keadaan tingkat produksi, jenis, dan jumlah konsumsi pakan serta individu ternak sendiri (Abdulgani, 1988). Sedangkan kotoran kambing teksturnya khas, karena berbentuk butiran-butiran yang agak sukar dipecah secara fisik sehingga berpengaruh terhadap proses penyediaan haranya. Pupuk kandang kambing akan lebih baik penggunaannya bila dikomposkan terlebih dahulu, kalau pun akan digunakan secara langsung, pupuk kandang ini akan memberikan manfaat yang lebih baik pada musim penanaman (Widowati et al., 2005). Ekskreta ayam merupakan salah satu limbah yang dihasilkan baik ayam petelur maupun ayam pedaging yang memiliki potensi yang besar sebagai pupuk organik. Komposisi kotoran sangat bervariasi tergantung pada sifat fisiologis ayam, ransum yang dimakan, lingkungan kandang termasuk suhu dan kelembaban. Kotoran ayam merupakan salah satu bahan organik yang berpengaruh terhadap sifat fisik, kimia, dan pertumbuhan tanaman (Taiganides, 1977).

Kotoran ternak merupakan bahan organik yang mempunyai prospek yang baik untuk dijadikan pupuk organik (bokashi), karna mempunyai kandungan unsur hara yang cukup tinggi. Bokashi adalah kompos yang dihasilkan melalui fermentasi dengan pemberian Effective Mikroorganisms-4 (EM4) yang merupakan salah satu aktivator untuk mempercepat proses pengomposan (Indriani, 2001). Berdasarkan bentuknya bokashi dibagi atas dua, yakni bokashi padat dan bokashi cair. Bokashi cair memiliki keuntungan seperti, dapat mendorong dan meningkatkan pembentukan klorofil daun, pembentukan bintil akar pada tanaman leguminosa sehingga meningkatkan kemampuan fotosintesis tanaman dan penyerapan nitrogen dari udara, dapat meningkatkan vigor tanaman sehingga tanaman menjadi kokoh dan kuat, meningkatkan daya tahan tanaman terhadap kekeringan, cekaman cuaca dan serangan pathogen penyebab penyakit, merangsang pertumbuhan cabang produksi, meningkatkan pembentukan bunga, mengurangi gugurnya daun dan bunga (Rizqiani et al., 2006)

Banyak hasil-hasil penelitian menunjukkan bahwa bokashi mempunyai kualitas yang lebih baik dibandingkan dengan teknik pengomposan sederhana. Pemberian bokashi yang difermentasikan dengan EM-4 merupakan salah satu cara untuk memperbaiki sifat fisik, kimia dan bilogi tanah, dapat menekan hama dan penyakit serta meningkatkan mutu dan jumlah produksi tanaman (Nasir, 2008). Dalam proses pembuatan bokashi terjadi peristiwa pengomposan yang merupakan proses perombakan bahan organik yang melibatkan mikroorganisme dalam keadaan terkontrol (Marsono dan Lingga, 2003). Proses perombakan atau dekomposisi bahan organik tersebut menjadi zat organik berbentuk ion tersedia bagi tanaman mendukung ketersediaan unsur hara, baik yang makro ataupun yang mikro. Upaya pemupukan sudah jelas mampu membantu penyediaan unsur hara serta akan menjadi lebih efektif apabila dilaksanakan dengan pemilihan cara, dosis, dan jenis pupuk yang tepat dan sesuai dengan kondisi tanaman.

\section{Metode Penelitian}

2.1 Waktu dan Lokasi Penelitian

Penelitian ini dilaksanakan pada kebun percobaan Fakultas Pertanian, Universitas Timor, Kelurahan Sasi, Kecamatan Kota, Kabupaten Timor Tengah Utara. Penelitian berlangsung selama 75hari

\subsection{Materi Penelitian \\ 2.2.1 Alat}

Peralatan yang digunakan terdiri dari alat ukur seperti; pengaris, jangka sorong, alat tulis, buku, meter, cangkul, linggis, parang, timbangan, ember, terpal, drum, gayung dan oven.

\subsubsection{Bahan}

Bahan yang digunakan seperti; lahan pertanian, bibit Centrosema pubescens dan bokashi cair, bahan yang digunakan untuk pembuatan bokashi cair adalah ekskreta ayam $12 \mathrm{~kg}$, feses sapi $12 \mathrm{~kg}$, dan feses kambing $12 \mathrm{~kg}$, EM4 1 botol, gula $36 \mathrm{~kg}$ dan air 240 liter.

\subsubsection{Rancangan Percobaan}

Penelitian menggunakan model experimen yang menerapkan Rancangan Acak Lengkap (RAL) dengan 4 perlakuan dan 4 ulangan. Adapun perlakuan yang diuji terdiri dari

$\mathrm{R}_{0} \quad=$ Tanpa bokashi cair

$\mathrm{R}_{1} \quad=$ Bokashi cair berbahan dasar feses Sapi

$\mathrm{R}_{2} \quad$ = Bokashi cair berbahan dasar feses Kambing

$\mathrm{R}_{3} \quad$ = Bokashi cair berbahan dasar ekskreta Ayam

\subsection{Prosedur Penelitian}

\subsubsection{Persiapan dan pengolahan lahan}

Lahan penelitian dibersihkan dari gulma, kemudian diolah dengan menggunakan cangkul, dan diolah dalam bentuk petak dimana tiap petak dibua dengan ukuran $120 \times 100 \mathrm{~cm}$ sebanyak 16 petak, jarak antara petak $30 \mathrm{~cm}$, dan jarak antara blok $50 \mathrm{~cm}$, tinggi petak dibuat dengan ukuran $20 \mathrm{~cm}$.

\subsubsection{Pembuatan pupuk bokashi cair}

Langkah-langkah pembuatan pupuk bokashi cair yaitu:

1. Menyediakan 3 drum, masing-masing drum ditambahkan 18 liter air.

2. Pada tempat terpisah, EM4 5 tutupan botol $(50 \mathrm{ml})$, gula $1 \mathrm{~kg}$, dilarutkan dalam 2 liter air dicampur dalam ember dan dibuat dalam masing masing ember kemudian diaduk sampai homogen dan dibiarkan selama 10-15 menit.

3. Kemudian menuangkan semua bahan yang sudah tercampur kedalam masing-masing drum yang sudah terisi air

4. Langkah selanjutnya aduk hingga merata dan masukkan ekskreta ayam /feses sapi /feses kambing sebanyak $2 \mathrm{~kg}$ kedalam masing-masing drum lalu diaduk secara perlahan hingga bahan tercampur secara keseluruhan.

5. Setelah itu masing-masing drum ditutup dengan rapat dan diletakkan ditempat teduh. Proses selanjutnya diamkan selama 1 minggu sebelum pupuk organik cair digunakan.

6. Langkah-langkah tersebut digunakan setiap minggu dalam proses pembuatan bokashi cair selama penelitian (6 kali perlakuan)

\subsubsection{Penanaman}

Penanaman sentro (Centrocema Pubescens) dengan menabur benih yang telah disiapkan dan di timbang sama perpetak yaitu $\pm 18 \mathrm{~g}$, sebelum menabur benih sentro dalam bentuk larikan dimana tiap petak terdiri dari 3 larikan, jarak antara larikan $25 \mathrm{~cm}$, panjang larikan $30 \mathrm{~cm}$, dan ditanam sedalam $5 \mathrm{~cm}$ dari permukaan tanah, setelah ditanam selanjutnya disiram menggunakan air. 


\subsubsection{Aplikasi perlakuan}

Pemberian perlakuan berupa bokashi cair dari feses sapi, ekskreta ayam dan feses kambing dilakukan sesuai perlakuan yang disusun. Pemberian bokashi cair bahan dasar berbeda di berikan pada waktu 7 hari setelah tanam dimana tiap penyiraman diberikan sebanyak 4 liter/petak dan tiap petak diberi sesuai perlakuan.

\subsubsection{Pemeliharaan}

Pemeliharaan dilakukan dengan melakukan penyiraman dan pembersihan gulma tiap hari. Penyiraman dilakukan dengan air biasa pada tiap pagi dan sore hari, sedangkan penyiangan dilakukan dengan mencabut tanaman liar yang hidup pada petak dan sekitarnya.

\subsubsection{Pengambilan data}

Pengambilan data dilakukan pada hari ke 7 setelah tanam, pengambilan data dilakukan setiap satu minggu sekali dan dilakukan selama lima kali pengukuran, yaitu pada panjang penyebaran, jumlah daun dan diameter batang.

\subsection{Variabel Penelitian}

Variabel yang diamati dalam penelitian ini yaitu

\subsubsection{Panjang penyebaran}

Pengukuran dilakukan dengan cara mengukur panjang tanaman yang menyebar(dilihat pada penyebaran yang paling panjang). Rumus yang digunakan sebagai berikut:

\section{$\frac{\mathrm{PP} 1+\mathrm{PP} 2+\mathrm{PP} 3+\mathrm{PP} 4+\mathrm{PP} 5}{\mathrm{~T}}$}

$$
\mathrm{T}
$$

Keterangan :

PP1 = Panjang penyebaran pengukuran pertama

PP2 = Panjang penyebaran pengukuran kedua

PP3 = Panjang penyebaran pengukuran ketiga

PP4 = Panjang penyebaran pengukuran keempat

PP5 $=$ Panjang penyebaran pengukuran kelima

$\mathrm{T}=$ Waktu

\subsubsection{Jumlah daun}

Pengukuran jumlah daun di lakukan dengan menghitung daun setiap tanaman. Rumus yang digunakan adalah sebagai berikut:

$\frac{\mathrm{JD} 1+\mathrm{JD} 2+\mathrm{JD} 3+\mathrm{JD} 4+\mathrm{JD} 5}{\mathrm{~T}}$

Keterangan :

JD1 = Jumlah daun pengukuran pertama

JD2 = Jumlah daun pengukuran kedua

JD3 = Jumlah daun pengukuran ketiga

JD4 = Jumlah daun pengukuran keempat

JD5 = Jumlah daun pengukuran Kelima

$\mathrm{T}=$ Waktu

\subsubsection{Diameter batang}

Diameter batang diukur di atas permukaan tanah. Pengukuran dilakukan dengan menggunakan jangka sorong. Untuk menghitung diameter batang digunakan rumus sebagai berikut:

\section{$\mathrm{DB}=\frac{\mathrm{DB} 1+\mathrm{DB} 2+\mathrm{DB} 3+\mathrm{DB} 4+\mathrm{DB} 5}{\mathrm{~T}}$}

Keterangan :

DB1 $=$ Diameter batang pengukuran pertama

DB2 $=$ Diameter batang pengukuran kedua

DB3 $=$ Diameter batang pengukuran ketiga

DB4 $=$ Diameter batang pengukuran keempat

DB5 = Diameter batang pengukuran kelima

$\mathrm{T}=$ Waktu

\subsection{Analisis Data}

Data hasil pengamatan kemudian dianalisis dengan menggunakan sidik ragam (Anova) RAL. Rata-rata perlakuan selanjutnya di uji lanjut dengan menggunakan Duncan Multiple Range Test (DMRT).

\section{Hasil dan Pembahasan}

\subsection{Panjang Penyebaran}

Panjang penyebaran merupakan salah satu kriteria untuk mengetahui laju pemanjangan tanaman sentro (Centrocema pubescens). Panjang penyebaran hasil penelitian terus bertambah dari awal pengamatan hingga akhir pengamatan. Hasil sidik ragam (Anova) menunjukkan bahwa perlakuan bokashi cair berbeda memberikan pengaruh yang nyata terhadap panjang penyebaran tanaman sentro. Panjang penyebaran tanaman sentro (Centrocema pubescens) dapat di lihat pada Gambar 1.

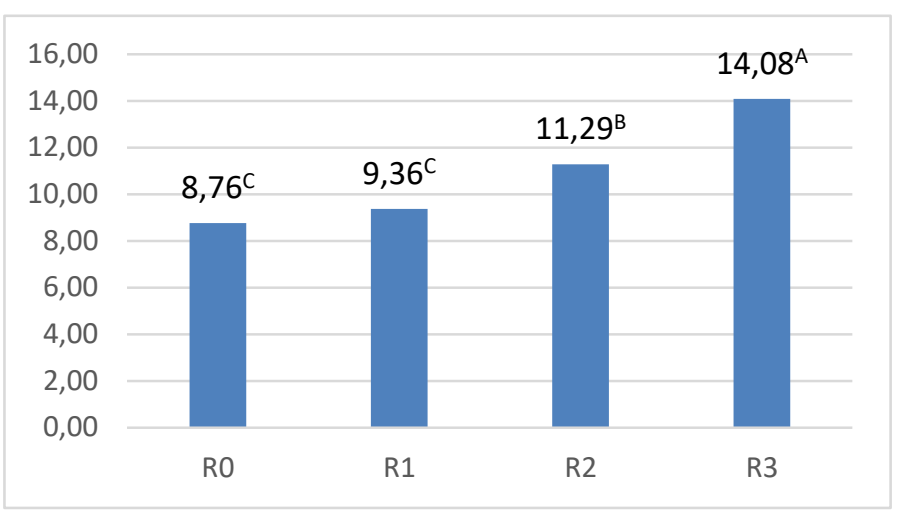

Gambar 1. Panjang Penyebaran (cm). Angka yang diikuti superscripct yang berbeda pada grafik diatas menunjukkan berbeda sangat nyata pada uji $\alpha 0.05$

Dari Gambar 1 hasil pengamatan produksi tertinggi pada panjang penyebaran yaitu perlakuan bokashi cair berbahan dasar ekskreta ayam $\left(\mathrm{R}_{3}\right)$ dengan rataan $14.08 \mathrm{~cm}$, kemudian diikuti perlakuan bokashi cair berbahan dasar feses kambing $\left(\mathrm{R}_{2}\right)$ yaitu dengan rataan $11,29 \mathrm{~cm}$, kemudian diikuti lagi oleh perlakuan yang diberi feses sapi $\left(R_{1}\right)$ yaitu dengan rataan $9,36 \mathrm{~cm}$, dan yang paling rendah yaitu pada perlakuan control $\left(\mathrm{R}_{0}\right)$ yaitu dengan rataan 8,76 $\mathrm{cm}$. Hal ini disebabkan karena tanaman banyak memperoleh unsur hara melalui ekskreta ayam karena mengandung unsur hara yang lebih banyak bila dibandingkan dengan pupuk kotoran sapi dan kambing. Kandungan unsur hara $\mathrm{N}$ pada ekskreta ayam hampir tiga kali lipat dibandingkan pupuk kotoran sapi, yaitu dalam ekskreta ayam terkandung N 2,79 \% dan pada kotoran sapi terkandung N 0,25\% (Nurhasanah et al., 2007). Satata dan Kusuma, (2014) menyatakan bahwa laju dekomposisi pupuk bokashi ekskreta ayam lebih cepat bila dibandingkan dengan pupuk kotoran sapi dan kambing sehingga unsur hara dapat cepat tersedia bagi pertumbuhan penyebaran tanaman. Sutedjo, (2002) juga menambahkan bahwa bahwa kebutuhan akan unsur hara $\mathrm{N}$ yang terdapat pada ekskreta ayam pada tanaman akan tercukupi selama pertumbuhan tanaman tersebut.

Pupuk organik umumnya merupakan pupuk lengkap karena mengandung unsur makro dan mikro meskipun dalam jumlah sedikit. Hakim et al. (1986) menyatakan terjadinya pertumbuhan penyebaran dari suatu tanaman karena adanya peristiwa pembelahan dan pemanjangan sel yang didominasi pada ujung pucuk tanaman tersebut. Proses ini merupakan sintesa protein yang diperoleh tanaman dari lingkungan seperti bahan organik dalam tanah. Hakim et al. (1986) menyatakan bahwa kekurangan $\mathrm{N}$ membatasi produksi protein dan bahan penting lainnya dalam pembentukan sel-sel baru. Unsur P berperan dalam proses pembelahan sel untuk membentuk organ tanaman. Kemudian ditambahkan oleh Sarief, (1986) bahwa unsur K merangsang titik-titik tumbuh tanaman.

\subsection{Jumlah Daun}

Jumlah daun merupakan salah satu kriteria untuk mengetahui laju pertumbuhan daun pada tanaman. Daun juga merupakan organ yang penting bagi tanaman dimana berperan dalam mensintesis makanan untuk kebutuhan tanaman maupun sebagai cadangan makanan (Ekawati et al., 2006). Dalam proses fotosintesis, dimana dalam pengolahannya menggunakan sinar matahari sebagai sumber energi selain itu juga di dalam daun terdapat klorofil yang akan berinteraksi dalam proses fotosintesis. Hasil pengamatan dapat dilihat pada Gambar 2.

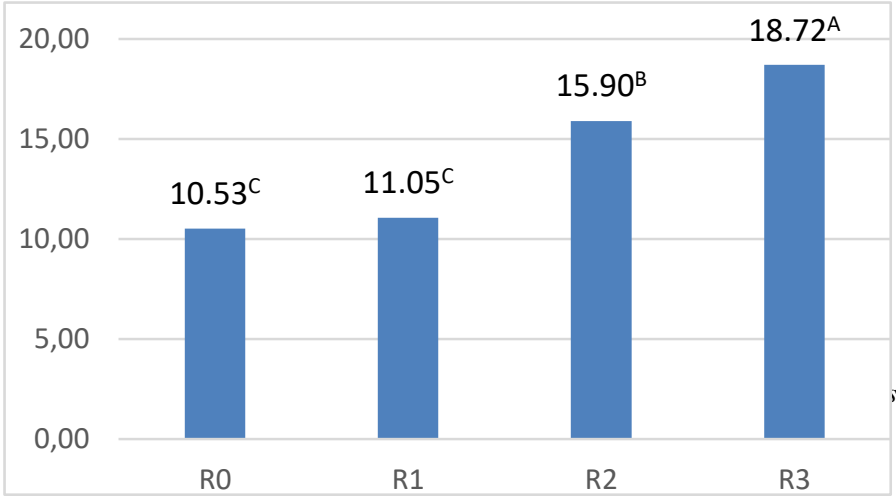

Gambar 2. Jumlah Daun (helai)

Jumlah daun selama penelitian mengalami penambahan seiring waktu tanam. Jumlah daun tertinggi ditunjukkan pada perlakuan tanaman sentro yang diberi bokashi dari bahan ekskreta ayam $\left(\mathrm{R}_{3}\right)$, yaitu jumlah daun sebanyak 18,72 helai diikuti perlakuan bokashi berbahan dasar feses kambing $\left(\mathrm{R}_{2}\right)$ 
sebanyak 15,90 helai, bokashi berbahan dasar feses sapi $\left(\mathrm{R}_{1}\right)$ sebanyak 11,05 helai, sedangkan jumlah daun terendah ditunjukkan pada perlakuan kontrol $\left(\mathrm{R}_{0}\right)$, yaitu jumlah daun sebanyak 10,53 helai. Hasil analisis sidik ragam (Anova) menunjukkan bahwa pemberian bokashi dari bahan dasar berbeda memberikan pengaruh nyata $(\mathrm{P}<0.05)$ terhadap jumlah daun tanaman sentro yang dihasilkan atau dengan kata lain bahwa pemberian bokashi dari bahan dasar berbeda menghasilkan karakter jumlah daun yang berbeda pada tiap perlakuan.

Secara umum memperlihatkan tumbuhan sentro yang diberi bokashi menghasilkan jumlah daun yang lebih tinggi dibandingkan kontrol. Hal ini karena kandungan yang tersedia di dalam pupuk bokashi yaitu kandungan nitrogen $(\mathrm{N})$, fosfor $(\mathrm{P})$, dan kalium $(\mathrm{K})$ yang sangat tinggi oleh sebab itu pupuk bokashi sangat berperan aktif dalam mempengaruhi jumlah daun. Nurhasanah et al. (2007) menyatakan bahwa dalam kotoran sapi terkandung $\mathrm{N}$ $0,25 \%$, P $0,01 \%$, K 0,56\%, kotoran kambing terdapat $\mathrm{N} 0,5 \%$, P $0,3 \%$ dan $\mathrm{K}$ $0,2 \%$, sedangkan dalam ekskreta ayam terkandung $\mathrm{N} 2,79 \%$, P $0,52 \%$ dan $\mathrm{K}$ $2,29 \%$. Banyaknya unsur hara yang tersedia dapat meningkatkan kesuburan daun yang cepat berubah dengan menumbuhkan tunas baru dan tunas muda menjadi banyak dan lebar dengan warna yang lebih hijau dan dapat meningkatkan kadar protein dalam tubuh tanaman. Nitrogen yang dibutuhkan untuk membentuk senyawa penting seperti klorofil, asam nukleat, dan enzim sedangkan unsur hara mikro berfungsi terutama dalam pembentukan daun dan klorofil pada daun. Apabila pembentukan daun tersebut terganggu maka proses fotosintesis akan terganggu bilamana ada kekurangan nitrogen, tanaman akan tumbuh lambat dan kerdil (Novizan, 2002). Komponen daun sangat membutuhkan unsur nitrogen dan fosfor terutama untuk pembentukan klorofil, unsur $\mathrm{N}$ juga berperan untuk merangsang pertumbuhan tanaman pada daun (Setiawan, 1998). Kandungan kalium yang terdapat pada bokashi berfungsi juga untuk pembentukan karbohidrat sehingga menghsilkan jumlah daun yang banyak (Sucipto, 2010). Bokashi dapat digunakan untuk meningkatkan kesuburan tanah melalui perbaikan sifat fisik, kimia dan biologi tanah Pengaruh terhadap sifat fisik tanah yaitu melalui pembentukan agregat tanah sehingga dapat memperbaiki struktur tanah. Pengaruh terhadap sifat kimia tanah adalah meningkatnya kandungan unsur hara tanah, sedangkan pengaruhnya jumlah daun dipengaruhi oleh nitrogen (Wijaya, 2008).

\subsection{Diameter Batang}

Diameter batang merupakan salah satu kriteria untuk mengetahui pertambahan ukuran batang tanaman. Diameter batang hasil penelitian terus bertambah dari awal pengamatan sampai akhir pengamatan. Diameter batang tanaman sentro (Centrocema pubescens) dapat dilihat pada Gambar 3.

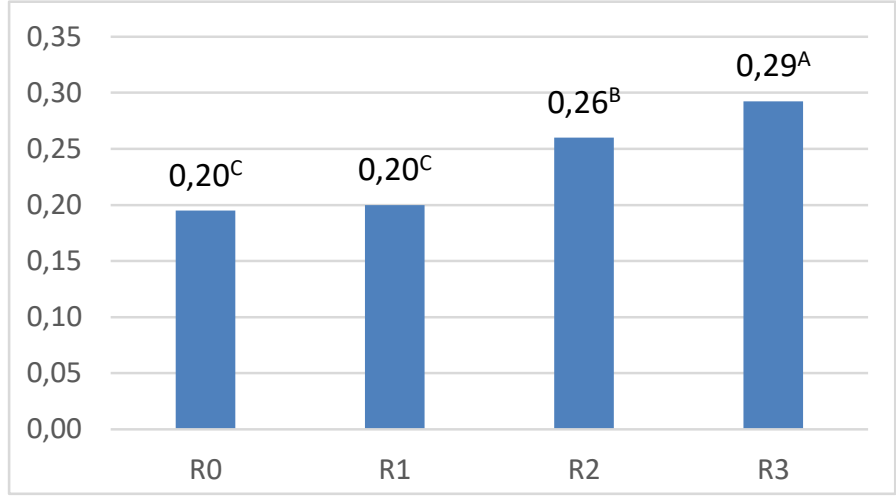

Gambar 3. Diameter Batang (cm). Angka yang diikuti superscripct yang berbeda pada grafik diatas menunjukkan berbeda sangat nyata pada uji $\alpha 0.05$

Hasil sidik ragam (Anova) menunjukkan pengaruh nyata antara bokashi cair berbahan dasar berbeda terhadap diameter batang sentro (Centrocema pubescens). Berdasarkan Gambar 3 diameter batang tanaman sentro (Centrocema pubescens) yang diberi perlakuan bokashi cair berbahan dasar ekskreta ayam $\left(\mathrm{R}_{3}\right)$ mempunyai diameter batang paling tinggi yaitu $0,29 \mathrm{~cm}$, kemudian diikuti oleh perlakuan bokashi cair berbahan dasar feses kambing $\left(R_{2}\right)$ yaitu $0,26 \mathrm{~cm}$, diikuti lagi oleh perlakuan bokashi cair dari feses sapi $\left(\mathrm{R}_{1}\right)$ yaitu $0,20 \mathrm{~cm}$, dan terendah adalah perlakuan kontrol $\left(R_{0}\right)$ yaitu $0,20 \mathrm{~cm}$. Hartatik dan Widowati, (2006) menyatakan bahwa bokashi cair ekskreta ayam terkandung N 1,3\%, P $1,21 \%$, K 1,39\%, kotoran kambing terkandung N 1,41\%, $\mathrm{P} 0,54 \%, \mathrm{~K} 0,75 \%$, sedangkan dalam feses sapi terkandung $\mathrm{N} 0,92 \%, \mathrm{P} 0,23 \%$, K $1,03 \%$. Dapat dijelaskan bahwa semakin kecil ternak kandungan unsur hara dalam kotorannya semakin tinggi dan akan memberi dampak terhadap pertumbuhhan tanaman (Lakitan, 2002). Hal ini membuktikan bahwa pemberian pupuk bokashi berbahan ekskreta ayam dapat menambah kelangsungan unsur hara dalam tanah sehingga dapat diserap oleh tanaman untuk merangsang pertumbuhan secara keseluruhan khususnya batang. Makin tinggi nitrogen yang tersedia bagi tanaman maka makin besar pula pertumbuhan batang pada tanaman. Dapat dijelaskan bahwa dengan kandungan unsur hara tersebut memacu pertumbuhan tanaman sentro yang optimal yang terlihat dari diameter batang tanaman. Semakin banyak tersedianya unsur kalium $(\mathrm{K})$ pada tanah dan bokashi cair dapat meningkatkan diameter batang tanaman semakin cepat bertambah panjang dan membesar. Ketersediaan unsur hara $\mathrm{K}$ perlu dicermati karena adanya fenomena konsumsi "mewah" (luxury consumption), yakni tanaman menyerap $\mathrm{K}$ melebihi kebutuhan untuk pertumbuhan optimumnya (Tisdale et al., 1985). Pertumbuhan tanaman berkorelasi dengan penambahan konsentrasi Kalium pada daerah pembesaran. Bila tanaman kekurangan kalium maka pembesaran dan perpanjangan sel terhambat (Bel dan Rahmania, 2001).

\section{Simpulan}

Berdasarkan hasil dan pembahasan dapat disimpulkan bahwa bokashi cair berbahan basar ekskreta ayam $\left(\mathrm{R}_{3}\right)$ menghasilkan jumlah daun sebanyak 18,72 helai, dimeter batang sebanyak $0,29 \mathrm{~cm}$ dan panjang penyebaran 14,08 $\mathrm{cm}$, dan lebih baik dibandingkan dengan yang diberi bokashi cair dari jenis feses kambing dan feses sapi.

\section{Daftar Pustaka}

Abdulgani, I. K., 1988. Seluk Beluk Kotoran Sapi Serta Manfaat Praktisnya. Fakultas Peternakan Institut Pertanian Bogor: Bogor

Bel dan AA. Rahmania. 2001. Telaah Faktor Pembatas Kacang Tanah Penelitian Palawija. 69 hal.

Ekawati. M. 2006. Pengaruh Media Multipikasi Terhadap Akar dan Tunas in Vitro Nenas. (Ananas comosus L Mer) cv. Smooth Cayeene Pada Media Penangkaran. Skripsi Jurusan Budidaya Pertanian. Fakultas Pertanian. Institut Pertanian Bogor.

Hakim. N. M. Y. Nyakpa. AM. Lubis. S.G. Nugroho. M.R. Saul. M.A. Diha G.B. Hong dan H.H Bailey. 1986. Dasar-Dasar Ilmu Tanah. Universitas Lampung.

Hartatik. W. dan L. R. Widowati. 2006. Pupuk Kandang. Dalam R. D. M. Simanugkalit. D. A. Suariadikarta. R. Saraswati. D. Setyorini. W. Hartatik (E ds). Pupuk Organik dan Pupuk Hayati. Balai Besar Litbang. Sumber Daya Lahan Pertanian. Badan Penelitian dan Pengembangan Pertanian. Bogor.

Indriani. Y. H. 2001. Membuat kompos secara kilat. Penebar Swadaya. Jakarta. Lakitan, B. 2002. Dasar-Dasar Klimatologi. Raja Grafindo Persada Jakarta.

Marsono dan Lingga. 2003. Membuat Kompos. Cetakan Ke Enam. PT. Swadaya. Jakarta.

Nasir. 2008. Pengaruh Penggunaan Pupuk Bokashi Pada Pertumbuhan Dan Produksi Padi Palawija Dan Sayuran http://www.dispertanak.pandeglang. Go.id/.diakses tanggal 9 januari 2020.

Nurhasanah, A., T. W. Widodo, Asari, dan Elita Rahmarestia. 2007. Perkembangan Digester Biogas di Indonesia (Studi Kasus di Jawa Barat dan Jawa Tengah). Balai Besar Pengembangan Mekanisasi Pertanian.

Novizan. 2002. Petunjuk Pemupukan Yang Efektif. Jakarta. Agro Media Pustaka.

Rizqiani, N.R., E. Ambarwati dan N. W. Yuwono. 2006. Pengaruh Dosis dan Frekuensi Pemberian Pupuk Organik Cair Terhadap Pertumbuhan dan Hasil Buncis (Phaseolus vulgaris L). Dataran Rendah. Ilmu Pertanian, Vol 13 (2) : 163-178.

Sarief. S. 1986. Kesuburan dan Pemupukan Tanah Pertanian. Pustaka Buana. Bandung

Satata. B. dan Kusuma. M. E. 2014. Pengaruh Jenis Tiga Pupuk Kotoran Ternak (Sapi, Ayam, dan Kambing) Terhadap Pertumbuhan dan Produksi Rumput Brachiaria Humidicola. Jurnal ilmu Hewani Tropika. 3(2). 5-9 ISSN : 2301-7783.

Setiawan. A. I. 1998. Memanfaatkan Kotoran Ternak. Penebar Swadaya. Jakarta.

Sutedjo, M. 2002. Pupuk dan Cara Pemupukan. Rineka Cipta. Jakarta. 72 hal.

Sucipto. 2010. Efisiensi Cara Pemupukan Terhadap Pertumbuhan dan Hail Beberapa Varietas Sorgum Manis. ( Sorgum Bicolor L, Moench). Jurnal Embryo 7 (2): 67-74.

Taiganides, R. E. 1977. Animal Waste. Applied Science publisher Ltd. London

Tisdale, S. L. Nelson W. L. dan Beatson. J.V 1985. Kesuburan Tanah dan Pemupukan. Penerbit Macmillan.

Widowati, L. R. Sri W.,U. Zainudin.,dan W. Hartatik. 2005. Pengaruh Kompos Organik Yang Diperkaya Bahan Mineral Dan Pupuk Hayati Terhadap Sifat-Sifat Tanah. TA 2005 (Tidak dipublikasikan).

Wijaya, K.A. 2008. Nutrisi Tanaman Sebagai Penentu Kualitas Hasil dan Resistensi Alami Tanaman. Prestasi Pustaka. Jakarta. 